CHAPTER 6:

\title{
Building Civic and Citizenship Education in the Dominican Republic
}

\author{
Ancell Scheker and Michelle Guzmán ${ }^{1}$
}

\begin{abstract}
This chapter addresses the participation of the Dominican Republic in the IEA International Civic and Citizenship Education Study (ICCS) 2009 and 2016, and the challenges they reveal. Participation in these IEA civic studies contributed to educational discussions in the Dominican Republic through stimulating curricular reform in which the education approach recently changed from content-based to competency-based. As a result, one of the core competencies to be developed in all subjects and at every grade through a cross-curricular approach is related to ethics and citizenship; specific contents regarding citizenship are taught in social sciences. However, ICCS has shown a substantial gap between the intended (formal curriculum documents), the implemented (actual teaching process in the classroom), and the attained curriculum (student achievement), as well as the importance of context. ICCS serves as a reliable source of information for policymaking, research, and debates regarding civic education in the Dominican Republic.
\end{abstract}

\section{Background}

The Dominican Republic is implementing substantial changes in its education system. Since 2013, it has allocated four percent of GDP to education, doubling the budget of the Ministry of Education. Several measures were taken to improve quality: investing more in early childhood education, gradually increasing instructional time, extending the school day from four to eight hours, reforming the curriculum and teachers' education, among others.

Changes in civic and citizenship education have been part of a broader transition in the system from a content-based approach (1995) to competency-based education (2016). The current curricular design, developed from 2013 to 2018, has defined competency as the "capability to act as an autonomous individual in different contexts; transforming concepts, procedures, attitudes and values in an integrated manner" (Ministerio de Educación 2016a, p. 40). It establishes seven core competencies and specific competencies in each subject. One of the core competencies is named "ethics and citizenship." This competency aims to develop in the students the ability to relate to others with respect, justice and equity in all settings, to question violent practices and those that violate human rights, and to transform society based on the principles of democracy (Ministerio de Educación 2016a, p. 65). These changes in the curriculum focus and approach are the result of a complex process, and highlight the continuing importance that the International Civic and Citizenship Education Study (ICCS) of the International Association for the Evaluation of Educational Achievement (IEA) has for informing policy and debate in the country.

In 2010, a new constitution was enacted giving a more active role to citizens. Learning the Dominican Constitution is an important part of the new curriculum. Moreover, a National Pact for the Reform of Education in the Dominican Republic (2014-2030) was agreed upon

1 Ancell Scheker is the Director of Evaluation of the Quality of Education at the Ministry of Education in Dominican Republic and Michelle Guzman was a consultant for the Ministry of Education. Authors wish to thank Marialejandra Guzmán and Anyelin Montero for their contribution in this chapter.

Ancell Scheker, Dirección de Evaluación de la Calidad, Ministerio de Educación, Santo Domingo, Dominican Republic email: Ancell.scheker@minerd.gob.do

Michelle Guzmán, Inicia Educación, Santo Domingo, Dominican Republic

email: michelle_mgt@hotmail.com

(C) IEA International Association for the Evaluation of Educational Achievement 2021

B. Malak-Minkiewicz and J. Torney-Purta (eds.), Influences of the IEA Civic

and Citizenship Education Studies, https://doi.org/10.1007/978-3-030-71102-3_6 
among government, teachers' union, nongovernmental organizations, political parties, academic institutions, and social and economic sectors. This National Pact emphasizes the importance of equipping students with ethic and citizenship consciousness, in order to make them aware of their rights and duties (Consejo Económico y Social 2014). Some of these recent education reforms, however, were not in place at the time the ICCS studies were conducted.

The Dominican Republic participated in both 2009 and 2016 ICCS studies. ${ }^{2}$ The results showed the Dominican Republic to be the Latin American country (of those participating in the study) with the most positive attitude towards authoritarian government when it brings economic benefits (Schulz et al. 2018b). The 2009 study also showed weaknesses of Dominican students in civic knowledge; most students performed on the lowest level of proficiency. In the second study, the results did not change; there was no statistically significant difference in the overall mean score between 2009 and 2016. However, there was a small increase in the percentage of students at the higher levels of performance, from $8.1 \%$ in 2009 to $12.2 \%$ in 2016 (Schulz et al. 2018a).

ICCS 2009 and 2016 results showed poor performance on the civic knowledge and citizenship competencies. Dominican students have also shown low levels of performance in other subjects like reading, math, and science assessed in international studies such as TERCE 2013 (UNESCO 2015) and PISA 2015 (OECD 2018); ${ }^{3}$ this indicates the general low quality of the education system, which is attributable to several factors. Dominican students are not familiar with standardized testing, and students' low reading ability is probably one factor associated with poor tests results and perhaps influences answers to attitudinal questions as well.

In addition to participating in the IEA ICCS project, the Dominican Republic started in 2018 to assess some competencies in citizenship and civics through its National Diagnostic Assessment. It assesses reading, mathematics, social studies, and science in grade 6 and 9 . The social studies test includes some items assessing a limited number of civics indicators that were established in the national curriculum developed in 2016-2017. In May 2018, grade 6 students completed this national test for the first time and results show that only $16 \%$ of students achieved the level of performance intended in the curriculum (Ministerio de Educación 2019). The grade 9 test was administered in May 2019 and results show that only 10\% of students achieved the satisfactory level of performance which is the one that meets curriculum aspirations (Ministerio de Educación 2020, in press). Thus, the information available on citizenship education for this chapter is mainly from the ICCS studies of 2009 and 2016; however, national assessments and international studies are consistent regarding low results in students' achievement.

For this chapter we consulted analyses utilizing the 2009 and 2016 data, and documented experiences. A review of the national curriculum and official documents provides context for civic and citizenship education. In addition, we interviewed four experts in the area of civics and citizenship education in the Dominican Republic. ${ }^{4}$

2 The ICCS study of 2009 was coordinated by the Directorate of Evaluation of Quality of Education (Dirección de Evaluación de la Calidad) from the Ministry of Education. For the ICCS study of 2016, the coordination was shared with the Dominican Institute of Evaluation and Research on Educational Quality (Instituto Dominicano de Evaluación e Investigación de la Calidad Educativa [IDEICE]).

3 TERCE = Third Regional Comparative and Explanatory Study; PISA = Programme for International Student Assessment.

4 We appreciate the collaboration of the experts interviewed who kindly provided timely information on the advances and challenges regarding citizenship in the Dominican education system: Sara Guilamo, professor at the Pontificia Universidad Catolica Madre y Maestra and coordinator of the Civic Education Consortium; Dr Leonor Elmúdesi, member of the Civic Education Consortium and principal of Lux Mundi school that implements Project Citizen; Dr Raymundo González, professor at the Instituto de Formación Docente Salome Ureña and coordinator of Social Sciences at the Department of Curriculum in the Ministry of Education until 2017; and Dr Josefina Zaiter, professor at the Universidad Autónoma de Santo Domingo and collaborator in ICCS studies. 


\section{Civics and Citizenship in the Education System}

In the late 1980s the Dominican education system was in a crisis of multiple dimensions, and all sectors agreed that reform was needed (Diaz 1996). As a result, and founded on the declaration of "Education for All" in the world conference held in Jomtien in 1990, a set of long-term reforms were developed, supported by all sectors related to education. The Ten-Year Plan (Plan Decenal 1992-2002), was one important milestone in education reforms and the evolving process of civic and citizenship education in the Dominican Republic.

In this section, we present the evolution of the curriculum related to civic and citizenship education. First, we review the curriculum of 1995 which is a product of the first Ten-Year Plan and then the most recent reform of 2016. However, it is important to remember that students' personal experiences in the social and political culture of the country have great influence on what they know and believe. For example, how can we expect that students will answer that a minister in government must pay a fine if he is speeding because we are all equal before the law (from an ICCS item; Schulz et al. 2018a) when in "real life" they know this does not happen. No policeman would stop someone from government, and he would not pay any fine. This contradiction between what the law states and what is observed in practice is experienced daily by individuals of all ages, students, and teachers. Perhaps the recognition of such contradictions is one reason why emphasis on applying knowledge in real situations was considered important in the curriculum reform of 2014-2018.

Looking back, the Dominican curriculum, published in 1995, established a cross-curricular approach for civic and citizenship education. Seven cross-curricular themes were defined, one of them being democracy and citizenship participation (Secretaría de Estado de Educación, Bellas Artes y Cultos 1994). The aim was for the school to become a place where democracy, participation, solidarity, justice, and equity were practiced. However, concerns arose because civics was no longer a specified subject matter. The individuals in favor of the cross-curricular approach affirmed that the previous designation of a specific subject had not helped to develop citizens who adopted democracy as their way of life (J. Zaiter, personal communication, November 12, 2018). On the other hand, the individuals in favor of civics being kept as a specific course believed that contents needed to have a specific place in the school schedule.

Four years later, the Education Act of 1999 established a specific program for moral and civic education (Secretaría de Estado de Educación, Bellas Artes y Cultos 1999) because the government and some sectors considered that the transversal approach proposed in the Ten-Year Plan 1992-2002 was insufficient. The Education Act of 1999, transformed the cross-curricular approach for civic and citizenship and it became a designated subject implemented one hour per week in basic and secondary education (Martínez et al. 2013). More emphasis was placed on the program in secondary education (grade 9 to 12).

The focus of the 1999 program was on concepts concerning the organization of the state, national symbols, civic values, citizens' rights and responsibilities, constitution and laws, and civic systems. The main contents of civic and citizenship education in the Dominican curriculum (1995-1999) were not necessarily the ones assessed in ICCS (Cox 2010). What was not included in the 1999 curricular program was participation in political actions (outside schools), strategies to solve conflicts, the judicial system, social cohesion, accountability, nationalism, and political participation (Cox 2010). The teaching strategies focused on learning definitions of the concepts and did not emphasize applying knowledge to specific situations or participating in projects to solve social problems.

In addition to the curriculum guidelines, students are also involved in school governance through the Student Council (Consejo Estudiantil). This Council was proposed in the Organic Regulation of Public Education Institutions, Act 4'99. The main function of the Student Council is to contribute 
to identifying and analyzing the school's needs and issues (as well as those of the community), with the intention of proposing solutions and ways of implementing them (Secretaría de Estado de Educación, Bellas Artes y Cultos 1999). Moreover, this Council is intended to take actions that promote the wellbeing of students, school, and community, as well as ensuring the fulfillment of the objectives proposed for education in the Dominican Republic. Even though the Student Council until today presents an opportunity to exercise democracy, teachers do not often take this opportunity to discuss possible actions with students or connect them to democratic principles. Therefore, students are not making connections between concepts and practices.

A subsequent Ten-Year Plan (2008-2018) recognized the need to revise the curriculum and paid more attention to implementation. Furthermore, the National Pact for the Educational Reform of the Dominican Republic 2014-2030 promoted a shared vision of education. It supports the principle that building citizenship requires an education that makes people conscious of their rights and duties, and also promotes respect for constitutional values. It encourages people to be autonomous, ethical, and socially responsible, as well as committed to gender equity, protection of the environment, and sustainable natural resources (Consejo Económico y Social 2014, p. 7).

Education and curricular reforms were developed gradually starting in 2014 with the initial documents that were the bases for the revision of the curriculum. The revised curriculum adopted a new competencies approach; it brought back the cross-curricular approach for teaching civics and citizenship in all areas at every grade and incorporated specific contents in social sciences. In addition, a new overall structure was in place; the education system was organized in six years of primary education and six years of secondary education. The curriculum was implemented gradually.

The Basis for the Curricular Update and Review (Bases de la Revisión y Actualización Curricular), published in 2014 and later in 2016, promotes an integral education that contributes to the autonomous and effective exercise of a democratic and ethical citizenship in a participatory, responsible, and conscious way (Ministerio de Educación 2016a). It encourages students in the first cycle of secondary education (grades 7, 8, and 9) to develop reflective and critical thinking as members of a democratic society founded in solidarity, justice, equity, and freedom (Ministerio de Educación 2016b). The new curriculum for grade 8 was implemented in the school year 2016-2017, after ICCS was administered.

As stated before, the new curricular design adopted a competency approach and established seven core or fundamental competencies to be taught across subject matters:

- Ethics and citizenship

- Communication

- Logic, creative, and critical thinking

- Problem solving

- Science and technology

- Environment and health

- Personal and spiritual development

In this curriculum, ethics and citizenship competency is the first of the seven core competencies that are expected to be developed across all subjects in all grades, and especially within social studies. Additionally, the curriculum portrays four components for the ethics and citizenship competency; which are:

(1) Recognizing oneself as a person belonging to a nation and its culture, and a global human culture.

(2) Assessing social and institutional practices from a historical perspective and within present times. 
(3) Contributing to the creation of fair, just, and democratic relationships that characterize harmonious living together.

(4) Acting with autonomy, responsibility, and assertiveness in relation to one's own rights and duties (Ministerio de Educación 2016a, p. 68).

The curriculum establishes that social studies be taught five hours per week, and citizenship education is a dimension within this subject area. Prior to the publication of the current curriculum in 2016, civics and citizenship education was focused on acquiring knowledge about national symbols, legal norms, and rights. Even though these elements are still present, "the main focus in the current curriculum is based on the exercise of citizenship and social problem solving," as stated by the former coordinator of social studies at the Department of Curriculum in the Ministry of Education of Dominican Republic (R. González, personal communication, November 13, 2018).

As this competency is cross-curricular, there is no specific textbook or other material. Its assessment is not specifically addressed but teachers can choose from the various strategies and tools for assessment described in the curriculum. It is based on mobilizing knowledge in particular situations where the students are expected to apply an understanding of the natural and social surroundings in solving problems, participate in debates or inquiry projects, and engage in teamwork. The curriculum suggests strategies that promote the participation of students. However, the implementation of the new curriculum is facing difficulties, not only in the area of civic and citizenship education (R. González, personal communication, November 13, 2018). Teachers need additional training and materials that give more specific guidance about how to deliver the curriculum and develop these competencies in the classroom.

As mentioned before, in the 2016 curriculum of lower-secondary education, ethics and citizenship does not have a specific time allocated in the daily schedule but is integrated within the subject area of social studies. Nevertheless, this competency also remains transversally related to other competencies in different subjects as well. For example, the main goal of the environmental and health competency is to offset the negative consequences generated by human actions in order to avoid future damages for our planet and to promote responsible citizenship based on the appreciation of the natural and social environment (Ministerio de Educación 2016a, p. 95). Therefore, this other competency is related to citizenship as well. Moreover, citizenship is also related to the competency of problem solving, and logical, critical, and creative thinking, among others, so connections must be made by the teacher and the students.

The way civics and citizenship are addressed in each classroom depends on the teacher. In the interviews held with experts for this chapter, concerns were voiced about the lack of focus on knowledge transmission in the process of civic education and the potential for subjectivity and teachers' beliefs to permeate activities and assessments. In addition, because the curriculum is very broad in its coverage, the effectiveness of teaching relies on teachers' skills. There are no materials or specific guidelines regarding how to present core competencies across subjects and how to assess them. In a country where teachers' education is, in general, of low quality, more specificity and more support are probably needed.

All experts interviewed raised concerns regarding civic and citizenship education teaching. Guilamo and Elmúdesi (personal communication, November 9 and November 14, 2018) expressed that some teachers think that having a specific space and time in the curriculum to teach civic and citizenship is necessary. Even if it were to remain as a cross-curricular competency, there should be a designated period in which civic knowledge could be transmitted and students could be made aware of the specific purpose of activities intended to promote citizenship. This concern is reinforced by the ICCS 2016 finding of lack of understanding of threats to democracy. Dominican students were the least likely of those in any of the countries that participated in the study to answer that it was bad for democracy when government officials gave jobs to their family 
or when government officials influenced the courts (Schulz et al. 2018a). As stated earlier, they had the lowest civic knowledge scores in 2009 and 2016. Therefore, specific instructional time used for improving students' civic knowledge and understanding appears to be vitally important.

School is recognized as one of the most important places to foster civic and citizenship practices, together with the family and the community (L. Elmúdesi, personal comunication, November 14, 2018). The school must set an environment that provides adequate situations for students to gain and mobilize knowledge through lessons that confront social and political realities. According to the current curriculum, the school is the proper space for fostering participatory decision making, teamwork skills, reflective practice, problem solving skills, and awareness of rights and duties (Ministerio de Educación 2016a). But this needs to be based on a foundation of knowledge of how democratic governments function.

There are important challenges in implementing practices that lead to citizenship competencies. In that sense, it is central to consider that discussions about teacher training and teaching strategies related to citizenship education are hampered when the social and political culture of the country is contrary to building or practicing citizenship and democratic values.

\section{Teachers of Civics and Citizenship}

Teachers in the Dominican Republic need to have a four-year bachelor's degree in education (licenciatura) from a university or higher education institution. Civic and citizenship teachers in the Dominican Republic are not required to have specific training in the area; most of them have a bachelor's in social sciences education. Nevertheless, nongovernmental organizations are contributing to teachers' education in civics and citizenship. The Poveda Cultural Center (Centro Cultural Poveda) is conducting a training program that helps teachers to implement an inquiryaction strategy to promote learning, and through that strategy work on civic and citizenship education (Centro Cultural Poveda 2018). Moreover, the Organization of Iberoamerican States (Organización de Estados Iberoamericanos), likewise, has a teachers' training program in civic and citizenship education (Zaiter 2018). Both programs are implemented in specific communities and are not widespread.

In addition to those nongovernment programs, the Consortium for Civic Education (Consorcio de Educación Cívica) in the Dominican Republic has been training teachers in civic and citizenship education since 1997. This larger Consortium is composed of nongovernmental organizations and schools and coordinated by the Pontificia Universidad Católica Madre y Maestra. In addition, this university developed a graduate program (diplomado) in civic education for in-service teachers, and hundreds have participated. However, training provided by the Consortium for Civic Education is a long way from permeating all schools in the Dominican Republic.

In 2001, with the support of the Center for Civic Education, United States, a model and mentors were provided for the development of the Citizenship Project, which was implemented in several schools. The resources for this program were a student manual and teacher guide adapted and translated by the Consortium and used for training of social studies teachers between 2001 and 2006 (Güilamo-Jiménez 2017). Therefore, there have been interesting formal experiences of teacher training in citizenship education but none of them has expanded and none continues to the present. 


\section{Presence of the IEA Civic and Citizenship Education Studies in Education Discourse and Reforms}

\section{Curriculum}

As mentioned, ICCS brought concerns about civic and citizenship education to the attention of several audiences in the Dominican Republic. In particular, this related to the low results, the non-democratic attitudes of many students, and perception of a lack of effective teaching.

The current curriculum gives significant importance to civic and citizenship education. Partly, this is supported by conclusions made about ICCS studies. Ethics and citizenship as a crosscurricular and core competency is intended to promote democratic involvement based on principles of participation, equity, intercultural aspects, justice, cooperation, and peace culture (Ministerio de Educación 2016a). It is hoped that teaching related to this competency will lead students to question, analyze, and criticize undemocratic and violent practices in their schools and communities. The document titled "Bases for the Curricular Update and Review" points out that through ethics and citizenship competencies, members of a society can create solutions to social problems (Ministerio de Educación 2016a). There is some evidence of increasing interest in educating citizens who value democracy, are critical about the current social reality, and are willing to become participatory members of the society (Zaiter 2018).

The results of the ICCS 2009 teachers' questionnaire showed that civic and citizenship education had only medium priority in comparison with the rest of the subject areas (Schulz et al. 2011). As a result, moral and civic education classes were frequently canceled for other activities or subjects (S. Güilamo-Jiménez, personal communication, November 9, 2018). In the current curriculum (2016), civic and citizenship as a core competency (ethics and citizenship) is expected to be present as part of all subjects, but the implementation has been difficult and there is no evidence of how this has been done. Our expert interviewees agreed that many people still believe that it is necessary to have a specific subject to teach civics and citizenship so the debate is not closed. However, there is a general agreement that practice is most important; if students have knowledge but do not have opportunities to put it in practice, it is not worth it. As stated earlier in this chapter, in the Dominican Republic laws may be written and known but many do not comply with them; hence, knowing is not enough.

The desire was to move beyond civic and citizenship education based only on memorizing norms and rights. Even though the current curriculum promotes positive practices of faceto-face interaction, the process has turned out to be a great challenge for teachers, for the school, and the community. This may be because of the prevalent culture of authoritarianism, due in part to the Dominican Republic's heritage and history of dictatorships (J. Zaiter, personal communication, November 12, 2018). Therefore, even though the current curriculum has a new approach and laudable goals, these are still far from being part of common classroom practices in Dominican schools.

In that regard, the Ministry of Education instituted national assessments starting in 2017 to have a baseline at the beginning of the curriculum implementation and continue monitoring curriculum development and achievement of students, taking into consideration the new curriculum learning indicators. Education Act 1-2016 establishes national assessments at the end of each cycle (grades 3, 6 and 9). In grade 6 and 9, civics and citizenship is included in the national test of social studies. This assessment does not have consequences for the promotion or grades of students, but each school receives a report of the results in each test. After analyzing their results, schools must develop a plan for improvement to be submitted to school districts. This is intended to allow school leaders to make decisions based on evidence to improve achievement. Therefore, ICCS studies have influenced, to a certain extent, the curriculum reform and the use of assessment to contribute to the improvement of the quality of education. 


\section{Pedagogy}

The new curriculum suggests strategies to foster an environment that promotes civic education goals. One of these strategies is the Classroom Participatory Project (Proyecto Participativo de Aula) which is an inquiry-action strategy developed within the school with the collaboration of parents, teachers, and the school community. Students are the center of this strategy. They work together and dialogue with the purpose of identifying the needs of their community, as well as ways to make positive changes. Classroom Participatory Projects were proposed with the aim to articulate the core competencies through an inquiry-action method. Families and the school community play an essential role in this strategy; they also support the processes of identifying community or school needs in order to create actions to improve those situations (Ministerio de Educación 2016b, p. 90). Classroom Participatory Projects create an environment to foster civic and citizenship education as it arises from the social reality around the school and community. It encourages dialogue and finding solutions.

These pedagogical strategies suggested by the new curriculum are believed to be well aligned with the concept of an active citizenship in a democratic society and more related to the competencies that need to be developed and that are assessed in the ICCS study. However, our interviewees mentioned that creating these changes in all classrooms is a huge challenge for those who are implementing civic and citizenship education in the Dominican Republic. This is because teachers do not have the preparation and training to work in that way. There is considerable doubt about whether the strategies in place and available resources will allow these intentions to be substantially implemented, evaluated, and disseminated.

One strategy, mentioned earlier, which has been implemented in schools that are part of the Civic Education Consortium is called Project Citizen (Proyecto Ciudadano). After the partnership with the Center for Civic Education ended some schools continued developing Project Citizen in certain areas. According to Güilamo-Jiménez (2017), this project intends to promote and strengthen citizenship education with the collaboration of the school community; it has the aim of creating a democratic and participatory society that allows the exercise of responsible citizenship. Tolerance, teamwork, effective communication, critical thinking, and problem solving, are some of the competencies promoted among students and members of the school community. There are concerns whether teachers and schools are prepared to incorporate these practices. Further there is uncertainty as to whether social and civic institutions are prepared for the participation of schools and students.

\section{Recent Trends in Teachers' Preparation for Civic Education Instruction}

Since civic and citizenship education has not been part of teachers' initial education programs, the needs of teacher education in this area are evident, especially given the poor results in ICCS 2009 and 2016.

In 2015 the Ministry of Higher Education, Science and Technology, created the Regulation for Quality Teacher Education in the Dominican Republic (Ministerio de Educación Superior, Ciencia y Tecnología 2015). This document describes the characteristics that programs for teachers' education should consider. This reform of teachers' education has the goal to enhance the quality of teaching, and all universities and institutions have to gradually transform their programs to a competency-based curriculum. Consequently, curriculum for teachers' education must focus on developing competencies that are aligned with the following dimensions:

- Professional and personal development dimension: draws attention to the ethical commitment that being a teacher implies, as well as to the professional development process.

- Sociocultural dimension: covers the competencies that teacher must have to according to 21st century skills and knowledge. 
- Knowledge of the student dimension: covers competencies that a teacher must have concerning ways to foster physical, biological, cognitive, and socio-emotional growth of their students at different stages of their development process.

- Pedagogical dimension: describes competencies related to the comprehension and development of elements involved in teaching and the learning process of the student.

- Curricular dimension: encompasses competencies related to knowledge of topics in the current curriculum and implementation of instruction in the domain of the subjects to be taught.

- School management dimension: describes teachers' competencies to support school management and leadership (Ministerio de Educación Superior, Ciencia y Tecnología 2015).

Civic and citizenship education is implicit in the "sociocultural dimension." The sociocultural competency includes the need for teachers to master techniques that promote the exercise of a local and global citizenship founded in moral values (Ministerio de Educación Superior, Ciencia y Tecnología, 2015). The regulation does not mention civics and citizenship as a specific subject in teacher training programs, paralleling the cross-curricular approach for students.

In spite of the reform of teachers' education programs, not all universities have changed their curriculum or include civic and citizenship education as a main objective or course. However, there is an interesting experience at the Instituto Superior de Formación Docente Salomé Ureña (ISFODOSU). This Institute is promoting principles of democratic citizenship and includes civic and citizenship education in its program for initial teachers' education (ISFODOSU 2018). The ISFODOSU is the main public institution for pre-service teacher education and has the second highest enrollment of those preparing for teaching careers.

In addition to reforming initial teachers' education, it is also necessary to plan a long-term strategy for in-service teachers at a national level (R. González, personal communication, November 13, 2018). There must be follow-up programs for teachers in order to help them develop an adequate environment to teach civics and citizenship in their classrooms (J. Zaiter, personal communication, November 12, 2018).

\section{Recognition of the School as a Community}

The ICCS 2016 reports mentioned the attention paid in the Dominican Republic's educational system to school governance, student participation, parent and community involvement in school, and values and school culture (Schulz et al. 2018b). These topics are present in the previous and current curriculum. However, there are some challenges.

ICCS 2016 showed that the percentages of students in the Dominican Republic who support hitting as a justified punishment are higher than the international average. Under the framework of the ethic and citizenship competency, the current curriculum expects that the school community will foster respect and a culture of peace. Therefore, the Ministry of Education, with the support of United Nations Children's Fund (UNICEF), launched a campaign called Peace Culture (Cultura de Paz) for the 2018 school year. This campaign promoted a harmonious coexistence in schools. Its purpose is to identify and analyze issues that are affecting coexistence in the school and to help identify positive ways to solve conflicts (Diario Hispaniola 2018).

Additionally, data from ICCS 2016 as well as PISA 2015 show a high level of bullying among Dominican students (Schultz et al. 2018a; OECD 2018). During the school year 2017-2018, a prevention campaign against bullying was launched and implemented. This campaign is called "I back you up against bullying" ("Yo te hago coro contra el bullying"); its purpose is to strengthen the peace culture of school communities through strategies that promote harmonious coexistence and respectful relationships. The suggested activities are described in a guide created for the implementation of this campaign in schools. This campaign takes into account students, families, school, and community. 
Moreover, as mentioned in the section before, some of the teaching strategies suggested by the curriculum such as classroom participatory projects are meant to integrate the community and promote learning of living together.

\section{Research Interests or Training of Researchers}

The results of ICCS 2009 were analyzed and a national report was published (Sistema Regional de Evaluación y Desarrollo de Competencias Ciudadanas 2010). Results were also discussed in a round table with specialists in civics and citizenship education in the Dominican Republic. From these conversations, a book titled Civic and Citizenship Education in the Dominican Republic was published in 2012 (Pepén Peguero 2012). This book had the support of the Latin American Faculty of Social Sciences (Facultad Lationamericana de Ciencias Sociales) and the Program to Promote Educational Reform in Latin America (Programa de Promoción de la Reforma Educativa en América Latina). The intention of the publication was to disseminate the results, analyses, concepts, and implications of ICCS 2009 in regards to education and society (Pepén Peguero 2012).

At present, the Dominican Institute of Evaluation and Research of Educational Quality (Instituto Dominicano de Evaluación e Investigación de la Calidad Educativa [IDEICE]) is analyzing the existing civic datasets from ICCS 2016.

Additionally, in July 2018, the Ministry of Education and other organizations held a Forum for Global Citizenship Education, Challenges and Opportunities, in the Dominican Republic. Attended by experts in civic and citizenship education and teachers, its aim was analyzing and discussing the challenges and opportunities to educate global citizens with the needed competencies for the new millennium (Pérez 2018). Further, in October 2018, the Ministry of Education, with the support of the Interamerican Development Bank, organized a seminar with more than 400 participants to discuss findings of ICCS 2016.

Furthermore, recommendations for research arose in the interviews held with specialists (November, 2018) in civic and citizenship education. For instance, it was suggested to use ICCS data to strengthen teacher training in civic and citizenship education and to educate principals and organizations that work with families in this area. In addition, it was suggested these results could be used for debating and reviewing policies, programs and strengthening teacher education programs in universities.

Researchers should be encouraged to use the ICCS database to develop more in-depth knowledge about this topic. Currently, IDEICE has been promoting use of the data to professors, students, and researchers. However, this is difficult because of a lack of culture of research in this area and, relatedly, a lack of capacity for research analyzing this type of data in the country.

\section{Perception of Civic and Citizenship Education in Society}

The results of ICCS 2016 and the regional module were presented in newspapers and in TV news and reports. The headline in one of the major newspapers (Periódico El Caribe) was "Students show tolerance for corruption and dictatorships;" and "67\% percent of students agree on doing justice by one's own hands if the authority does not work" (Morel 2018a, 2018b). These publications highlighted that only $1.2 \%$ of students in the Dominican Republic are reaching the highest level of civic knowledge (Morel 2018a).

One TV news program expressed the opinion that society has been distracted with other issues and little attention has been paid to the "alarming situation" revealed by the ICCS study. Concern was expressed that future citizens (our students) justified corruption and dictatorship and that substantial numbers indicated that they do not believe in the values of democracy. ${ }^{5}$ The general

5 Opinion expressed by Ricardo Pérez Fernández, August 8, 2018. Telenoticias, Local news Channel 11. 
perception is that the education system is not teaching the values and practices needed to have a democratic and sustainable society.

However, schools are social institutions. In a society with the prevailing belief that democracy is not working this can result in an ambivalent discourse driven by concern about a lack of moral values coupled with, at the same time, being accustomed to tolerating practices of corruption. We see, on the one hand, complaints when laws are violated but on the other hand, acceptance of a law violation if it "solves my problem." Social practices that the younger generations observe are more important than the schools' intentions (Valera 2012). Thus, students may be more influenced by what they see in society and the prevalent political culture than what they are taught in classrooms.

\section{Conclusion}

There is widespread concern regarding the perception that students in the Dominican Republic are not being educated to become good citizens. Although this concern is very clear in all discourses, relatively few actions are being taken. It is also necessary to understand that building citizenship is not only the responsibility of schools or the education system; it is necessary to involve other social and political institutions, as well as the media.

Participating in ICCS 2009 and 2016 made visible to educators and the public in the Dominican Republic the huge challenge of improving civic knowledge and citizenship competencies. It also revealed that between 2009 and 2016 little was done to improve these competencies and consequently there was no improvement in the results.

The education system tends to focus on other subjects that are easier to assess like reading or mathematics, and may expect that civic knowledge and values will be learned in other contexts. Certainly, civics and citizenship are competences that are not learned only in schools, but it should be recognized that the school has a fundamental role to play. If the educational community does not pay attention to results such as those in the ICCS studies and does not consider initiatives to promote learning in civic and citizenship education, our future as a democratic nation is uncertain.

ICCS results have influenced, to a certain extent, some of the actions that have been taken, such as curricular reform, and the incorporation of citizenship topics in national assessments. However, resources and programs that support specific aspects of the teaching of civics and citizenship have not been developed.

What happens in practice in the country-that laws and norms are established but not followedis also observed with the curriculum. There is a substantial gap between the formal prescribed national curriculum, its implementation in the classrooms, and student achievement. Context, social, and cultural practices, and teachers' characteristics as well as students' beliefs, experiences, and knowledge mediate teaching and learning processes. There is still much to learn by analyzing the ICCS comparative data to inform policies and practices.

The Dominican Republic has decided to continue its participation in the forthcoming ICCS studies to monitor our progress (or lack of it) and the effects of policies that are in place like the new curriculum, as well as to continue the discussion within the country of best practices to promote citizenship. Significantly, the use of evidence to inspire a common effort to improve the quality and equity of education and change the political and social culture towards achieving a more just society has been recognized as important. In part this is a result of our participation in ICCS. 


\section{References}

Centro Cultural Poveda. (2018). Proyectos Participativos de Aula (PPA). http://www.centropoveda.org/ Proyectos-Participativos-de-Aula.html

Consejo Económico y Social. (2014). Pacto nacional para la reforma educativa en la República Dominicana 2014-2030. https://www.ces.org.do/ArchivosPortalCES/PACTO-NACIONAL-PARA-LA-REFORMAEDUCATIVA-suscrito-1-abril-2014.pdf

Cox, C. (2010). Informe de Referente Regional 2010: Oportunidades de aprendizaje escolar de la ciudadanía en América Latina: currículos comparados [Report on regional references 2010. Opportunities for learning about citizenship in Latin America: A comparison of curricula]. Bogotá, Colombia: Regional System for the Development and Evaluation of Citizenship Competencies.

Diario Hispaniola. (2018, September). Ministerio de Educación lanza estrategia nacional para una Cultura de Paz en las escuelas. https://www.diariohispaniola.com/noticia/45185/nacional/ministerio-de-educacionlanza-estrategia-nacional-para-una-cultura-de-paz-en-las-escuelas.html

Díaz, M. (1996). Educación y Modernización Social en República Dominicana: Un análisis sociológico del Plan Decenal [Education and social modernization in the Dominican Republic: a sociological analysis of the Ten-Year Plan]. Santo Domingo, Dominican Republic: Corripio.

Güílamo-Jiménez, S. (2017). Proyecto Ciudadano. Una estrategia para desarrollar empoderamiento social en el ciclo de los Estudios Generales y el currículo por competencias [Citizen Project. A strategy to develop social empowerment in the General Studies cycle and the competency curriculum]. University Pedagogy Notebook, 14(28), 50-60. https://doi.org/10.29197/cpu.v14i28.292

Martínez, Á., Zaiter, J., Valeirón, J., Scheker, A., \& Cohen, M. (2013). Dominican Republic. In J. Ainley, W. Schulz, \& T. Friedman (Eds.), ICCS 2009 encyclopedia: Approaches to civic and citizenship education around the world (pp. 121-128). Amsterdam, the Netherlands: International Association for the Evaluation of Educational Achievement (IEA).

Ministerio de Educación de la República Dominicana. (2016a). Bases de la Revisión y Actualización Curricular. Santo Domingo, Dominican Republic: Author.

Ministerio de Educación de la República Dominicana. (2016b). Diseño Curricular Nivel Secundario Primer Ciclo. Santo Domingo, Dominican Republic: Author.

Ministerio de Educación de la República Dominicana. (2019). Resultados de la Evaluación Diagnóstica Nacional de Sexto Grado de Primaria, Informe Nacional. Santo Domingo, Dominican Republic: Author. http://www.ministeriodeeducacion.gob.do/docs/direccion-de-evaluacion-de-la-calidad/AWZB-informenacional-evaluacion-diagnostica-sexto-grado-2018pdf.pdf

Ministerio de Educación de la República Dominicana. (2020, in press). Resultados de la Evaluación Diagnóstica Nacional de Tercer Grado de Secundaria, Informe Nacional. Santo Domingo, Dominican Republic.

Ministerio de Educación Superior, Ciencia y Tecnología. (2015). Normativa para la Formación Docente de Calidad en la República Dominicana. Santo Domingo, Dominican Republic: Author.

Morel, M. (2018a, July 31). 67\% valida hacer justicia por mano propia si autoridad no funciona. Periódico El Caribe. https://www.elcaribe.com.do/2018/07/31/panorama/pais/67-valida-hacer-justicia-por-manopropia-si-autoridad-no-funciona/

Morel, M. (2018b, July 30). Estudiantes muestran tolerancia a la corrupción y dictaduras. Periódico El Caribe. https://www.elcaribe.com.do/2018/07/30/panorama/pais/estudiantes-muestran-tolerancia-lacorrupcion-y-dictaduras/

Organisation for Economic Co-operation and Development (OECD). (2018). PISA 2015 results in focus. Paris, France: OECD.

Pepén Peguero, M. (Ed.). (2012). La Educación Cívica y Ciudadana en República Dominicana. Santo Domingo, Dominican Republic: Facultad Lationamericana de Ciencias Sociales.

Pérez, A. (2018, July 6). Foro de Formación en Ciudadanía Global, Retos y Oportunidades en RD. Impulsar. https://impulsar.org/2018/07/foro-de-formacion-en-ciudadania-global-retos-y-oportunidades-en-rd/

Secretaría de Estado de Educación, Bellas Artes y Cultos. (1994) Fundamentos del Curriculum Tomo II: Naturaleza de las áreas y Ejes Transversales. Santo Domingo, Dominican Republic: Taller.

Secretaría de Estado de Educación, Bellas Artes y Cultos. (1999) Ordenanza 4-99. Reglamento de Instituciones Públicas. Santo Domingo, Dominican Republic: Taller. 
Sistema Regional de Evaluación y Desarrollo de Competencias Ciudadanas. (2010). Informe Nacional de Resultados: República Dominicana, Estudio Internacional de Educación Cívica y Ciudadana ICCS 2009. Bogotá, Colombia: Author.

Schulz, W., Ainley, J., Fraillon, J., Lostio, B., Agrusti, G., \& Friedman, T. (2018a). Becoming citizens in a changing world. IEA International Civic and Citizenship Education Study 2016 international report. Cham, Switzerland: Springer. https://doi.org/10.1007/978-3-319-73963-2

Schulz, W., Ainley, J., Friedman, T., \& Lietz, P. (2011). ICCS 2009 Latin American report. Civic knowledge and attitudes among lower-secondary students in six Latin American countries. Amsterdam, the Netherlands: International Association for the Evaluation of Educational Achievement (IEA).

Schulz, W., Ainley, J., Cox, C., \& Friedman, T. (2018b). Young people's views of government, peaceful coexistence, and diversity in five Latin American countries. IEA International Civic and Citizenship Education Study 2016 Latin American report. Cham, Switzerland: Springer.

UNESCO-OREALC. (2015). Informe de resultados TERCE: Iogros de aprendizaje. Paris, France: UNESCO Office Santiago and Regional Bureau for Education in Latin America and the Caribbean.

Valera, C. (2012). La Educación Ciudadana en República Dominicana: Análisis de los resultados del Estudio Internacional de Educación Cívica y Ciudadana (ICCS 2009). In M. Pepén Peguero, La Educación Cívica y Ciudadana en República Dominicana (pp. 47-53). Santo Domingo, Dominican Republic: Facultad Lationamericana de Ciencias Sociales.

Zaiter, J. (2018). Estudio Internacional de Educación Cívica y Ciudadanía. ICCS 2016. Santo Domingo, Dominican Republic. (Manuscript in preparation).

Open Access This chapter is licensed under the terms of the Creative Commons Attribution-NonCommercial 4.0 International License (http://creativecommons.org/licenses/by-nc/4.0/), which permits any noncommercial use, sharing, adaptation, distribution and reproduction in any medium or format, as long as you give appropriate credit to the original author(s) and the source, provide a link to the Creative Commons license and indicate if changes were made.

The images or other third party material in this chapter are included in the chapter's Creative Commons license, unless indicated otherwise in a credit line to the material. If material is not included in the chapter's Creative Commons license and your intended use is not permitted by statutory regulation or exceeds the permitted use, you will need to obtain permission directly from the copyright holder. 